\title{
Abstract and Concrete Reasonableness Review by the European Court of Human Rights
}

\author{
Janneke Gerards \\ Professor of Fundamental Rights Law, Montaigne Centre for Rule of Law and \\ Administration of Justice, Utrecht University, Utrecht, The Netherlands \\ j.h.gerards@uu.nl
}

\begin{abstract}
In many cases, the ECtHR is clearly asked to examine an individual decision, such as an administrative or court decision, but many other applications concern the reasonableness of interferences caused by national legislation. At present, there appears to be considerable confusion and controversy with the Court's judges as to whether its review in the second category of cases should be concrete (focussing on the individual case only), abstract (focussing on the legislative system as a whole), or both (or a hybrid). This article presents a systematic and qualitative analysis of the Court's case law to find out which approaches it takes to the reasonableness review of legislation in which types of cases. Based on the results of the analysis it further endeavours to answer the question of which approach would best fit the Court's double role of delivering both individual and general justice.
\end{abstract}

\section{Keywords}

judicial review - European Court of Human Rights - abstract review - concrete review - individual v general justice - review of legislation - reasonableness review

The European Court of Human Rights (ECtHR or Court) plays a crucial double role in protecting fundamental rights. ${ }^{1}$ On the one hand, the ECtHR has the

1 See in particular R Harmsen, 'The Reform of the Convention System: Institutional Restructuring and the (Geo-)Politics of Human Rights' in J Christoffersen and M Rask Madsen (eds.), 
task of delivering individual justice. ${ }^{2}$ Victims of (alleged) violations of Convention rights can lodge an application at the Court, which it will then (if admissible) assess on its merits. ${ }^{3}$ This can result in a finding of a violation in the concrete case, which may go together with an obligation to pay just satisfaction for the material or immaterial damage that the applicant has suffered. ${ }^{4}$ The States are allowed and encouraged, but not obliged, to draw broader inferences from these judgments. ${ }^{5}$

On the other hand, and simultaneously, the Court has adopted a constitutional role. ${ }^{6}$ Based on Article $32 \mathrm{ECHR}$, the Court often defines 'general principles' related to the interpretation and application of the Convention, which can be applied regardless of the facts and circumstances of the individual case. ${ }^{7}$ In addition, the Court has developed several strategies directed towards delivering general justice. ${ }^{8}$ For example, it quite frequently suggests that a

The European Court of Human Rights between Law and Politics (Oxford, OUP 2011) 119, 131; F de Londras, 'Dual functionality and the persistent frailty of the European Court of Human Rights' (2013) European Human Rights Law Review (1) 38; LR Glas, 'Changes in the Procedural Practice of the European Court of Human Rights: Consequences for the Convention System and Lessons to be Drawn' (2014) 14 Human Rights Law Review 671; OM Arnardóttir, 'The Brighton Aftermath and the Changing Role of the European Court of Human Rights' (2018) 9 Journal of International Dispute Settlement 223; JH Gerards, 'Margin of Appreciation and Incrementalism in the Case-Law of the European Court of Human Rights' (2018) Human Rights Law Review 495.

2 In more detail, see JH Gerards and LR Glas, 'Access to justice in the European Convention on Human Rights system' (2017) 35 Netherlands Quarterly of Human Rights 11.

3 Article 34 ECHR.

4 Article $41 \mathrm{ECHR}$.

5 Article 46 ECHR; Gerards (n 1) 506; see also E Klein, 'Should the binding effect of the judgments of the European Court of Human Rights be extended? ' in P Mahoney (ed.), Protecting Human Rights: the European Perspective (2000) 705, 706; G Ress, 'The Effect of Decisions and Judgments of the European Court of Human Rights in the Domestic Legal Order' (2005) 40 Texas International Law Journal 359, 374.

6 Cf eg EA Alkema, 'The European Convention as a Constitution and its Court as a Constitutional Court' in P Mahoney et al. (eds.), Protecting Human Rights: The European Perspective Studies in Memory of Rolv Ryssdal (Cologne, Carl Heymans Verlag 2000) 41; L Wildhaber, 'A Constitutional Future for the European Court of Human Rights?' (2002) 23 Human Rights Law Journal 161; W Sadurski, 'Partnering with Strasbourg: Constitutionalisation of the European Court of Human Rights, the Accession of Central and East European States to the Council of Europe, and the Idea of Pilot Judgments' (2009) 9 Human Rights Law Review 397, 412ff; S Greer and L Wildhaber, 'Revisiting the Debate about 'constitutionalising' the European Court of Human Rights' (2012) 12 Human Rights Law Review 655, 667-9; JH Gerards, 'The European Court of Human Rights' in A Jákab et al. (eds), Comparative Constitutional Reasoning (Cambridge, CUP 2017).

7 Gerards (n 1) 507.

8 Gerards and Glas (n 2). 
State adopt 'general measures' in response to a judgment with the objective of guaranteeing Convention compliance beyond the individual case, ${ }^{9}$ and it increasingly often identifies structural or systemic problems underlying a concrete violation of the Convention. ${ }^{10}$

Much has been written on this double role of the Court and its consequences for the Court's procedure and approach to argumentation. ${ }^{11}$ There is one particular aspect, however, that has remained underexplored. This concerns the Court's proper object of review. ${ }^{12}$ In many cases the object of the Court's review is clearly an individual decision, in line with its task to offer individual justice. Such review is applied, for example, if the complaint concerns a national court's judgment to deny parental rights to an applicant, a judicial decision to extend a suspect's detention, or an administrative decision to expropriate someone's land. In those cases, the individual decision is at the very heart of the complaint and it is logical that the Court looks into the particular circumstances of the case to see if the interference was necessary and

9 Based on Article 46 ECHR. See further on this focus on 'substantive' justice, alongside 'individual justice', Gerards and Glas (n 2).

10 The pilot judgment procedure laid down in Rule 61 of the Rules of Court illustrates how the Court can sometimes identify and help to solve structural or systemic problems. This procedure allows the Court to identify a general, abstract violation of the Convention that goes beyond the merits of the individual case, and assist the State in deciding on the general changes needed to remedy the violation. Once such changes have been made on the domestic level and have been found to be satisfactory by the Court, it can strike out all similar individual cases or declare them inadmissible, requiring them to seek individual justice at the national level. See further, LR Glas, 'The Functioning of the Pilot-Judgment Procedure of the European Court of Human Rights in Practice' (2016) 34 Netherlands Quarterly of Human Rights 41 and see Gerards and Glas (n 2) 27, with many further references. In addition, based on Article 46 ECHR, the Court can make suggestions for remedying structural violations without resorting to a pilot judgment procedure; see on its use of this possibility, eg Glas (n 1 ). More recently, the existence of this double role has been reconfirmed by the adoption of Protocol 16; this is clear, in particular, from the first advisory opinion of the Court: Advisory opinion concerning the recognition in domestic law of a legal parent-child relationship between a child born through a gestational surrogacy arrangement abroad and the intended mother, Requested by the French Court of Cassation, ECtHR (Grand Chamber) 10 April 2019, P16-2018-oo1, para 26, where the Court held that, on the one hand, 'the opinions it delivers under this Protocol must be confined to points that are directly connected to the proceedings pending at domestic level'; on the other hand, however, the Court remarked that ' $[\mathrm{t}$ ] heir value also lies in providing the national courts with guidance on questions of principle relating to the Convention applicable in similar cases'.

11 Ibid.

12 See, however, JH Gerards, General Principles of the European Convention on Human Rights (Cambridge, CUP 2019) chapter 2. 
proportionate to the aims pursued. Hence, the Court's reasonableness review will focus on the individual decision and it will be specific in nature.

Many other applications made to the Court concern the reasonableness of interferences of the Convention caused by national legislation or by decisions applying that legislation in a specific case. To illustrate, the judgment of the Court in the so-called 'bedroom tax' case can be mentioned: JD and $A v$ the United Kingdom..$^{13}$ The case concerned an amendment of housing benefits legislation in the United Kingdom that had the aim of bringing the level of housing benefits received by beneficiaries in the social rented sector in line with the number of bedrooms in their home. In many cases this led to a reduction of the benefits, for example if two beneficiaries were living in a house with three bedrooms. If such a reduction occurred, it was possible for a beneficiary to make use of the discretionary housing payments (DHP) system, which could lead to the allocation of a special allowance to compensate for the reduction. The first applicant in the $J D$ and $A$ case lived in a three-bedroom house together with her severely disabled daughter, whose special needs the house was specifically designed to accommodate. As a result of the amendment of the legislation, her housing benefits were reduced by 14 per cent because she was considered to have one more bedroom than she was entitled to. ${ }^{14}$ The applicant successfully applied for DHP to meet the difference, but in her view the legislative amendment and the concomitant requirement to continue to apply for DHP resulted in substantive discrimination. In its assessment of her complaints, the Court chose to take the national legislative system as a whole as the object of its assessment. ${ }^{15}$ In so doing it noted that the availability of the DHP scheme provided for cases of special hardship and allowed local authorities to make individualised decisions, as had also happened in the case of the first applicant. ${ }^{16}$ Consequently, it concluded that the legislation was proportionate and did not constitute unjustified discrimination. ${ }^{17}$

It follows from this that the Court reviewed the case of the first applicant in $J D$ and $A$ in abstracto, focussing on the reasonableness and proportionality of the legislative system as a whole. It did not look into the specifics of the applicant's case and it did not assess if, for example, the obligation to apply for temporary DHP had placed an excessive individual burden on her. This approach was criticised by two (partly) dissenting judges, who stated that it would have been necessary for the Court to consider a number of factors related to the

13 JD and $A v$ the United Kingdom App nos 32949/17 and 34614/17 (ECtHR, 24 October 2019).

14 Ibid para 8.

15 Ibid para 100.

16 Ibid para 102.

17 Ibid para 102. 
personal situation of the applicant, such as her financial situation and the existence of other sources of income. ${ }^{18}$ According to the dissenting judges, the lack of attention to such factors rendered the Court's proportionality assessment 'irrational' and its reasoning provided insufficient grounds to draw any conclusions regarding the national decision's reasonableness. ${ }^{19}$

This example shows, first, that the object of the Court's reasonableness review may make a difference for the outcome of a case. ${ }^{20}$ Had the Court looked into the concrete situation of the first applicant, it might have arrived at a different finding. Second, it demonstrates that the Court is not always very clear as regards the role it wants to play and the type of review it wants to conduct. Indeed, as the dissenting judges in the bedroom tax case noted,

[i]n some cases the Court, while assessing the reasonable relationship of proportionality, examines the contested legislative measures in abstracto, looking at general issues ... while in other cases it also assesses the impact of the measures in concreto, i.e. by looking into the individual situation of the applicant. ${ }^{21}$

The partly dissenting opinion to the bedroom tax case thus both discloses that the Court's approach to the matter of concrete or abstract review is not fully consistent, and that the choice for one or the other approach is a matter of controversy within the Court. ${ }^{22}$

Against this background, the present article aims to explore the issue of concrete and abstract reasonableness review in the ECtHR's case law. The main question to be answered is an analytical one: how does the Court deal with the issue of abstract and concrete reasonableness review in its case law, and is it possible to identify any general threads and arguments in its judgments that can help explain its choice for a certain object of review? In turn, the outcomes of this analysis may help to answer another, rather more evaluative question:

18 Ibid Joint partly dissenting opinion of Judges Wojtyczek and Pejchal, para 7.

19 Ibid.

20 It may be important to note that this article does not focus on the requirement that a violation must be 'provided by law' or 'have a basis in domestic law'. It concentrates on the review of the necessity, proportionality or overall reasonableness of the interference disclosed by the case before the Court.

$21 J D$ and $A\left(\mathrm{n}_{13}\right)$ Joint partly dissenting opinion of Judges Wojtyczek and Pejchal, para 3.

22 This was pointed out by (former ECtHR, judge) Tulkens (F Tulkens, 'Different standards of judicial review. The nature and object of the judgment of the European Court of Human Rights' (2011) 4 Constitutional Law Review 31, 34. Such controversy can be seen also from separate opinions in the cases under study; see further Section 3 . 
what would be the best way for the Court to approach the object of its review, also in light of its double role in the overall ECHR system?

As a basis for answering these questions, it is useful to briefly explain how the Court can be confronted with the choice between abstract and concrete reasonableness review at all, given that its competence is, strictly speaking, restricted to deciding on individual applications concerning concrete violations of the Convention. This matter is discussed in Section 2. Section 3 then presents a systematic, qualitative analysis of the Court's case law on the object of its review. The point of departure for this analysis is that, theoretically and logically, four different options are available in relation to reasonableness review: (a) purely concrete review, (b) a combination of concrete and abstract review, (c) purely abstract review, and (d) a hybrid of concrete and abstract review. ${ }^{23}$ Around 100 judgments involving reasonableness review have been studied to identify if the Court's review can be classified as one of these four forms. In addition, the judgments have been analysed to see if the Court's reasoning contains an explanation for its choice of approach (and if so, what explanation is given), whether the choice was controversial within the Court (as can be derived from separate opinions focussing on this point), and if any other factors can be seen in the case that could explain the choice made by the Court. It turns out that each of the four theoretical categories are indeed present in the Court's case law. To demonstrate, Section 3 discusses a number of representative examples of the case law for each of them. In addition, for each category, and as much as the case law allows, insight is given in the Court's arguments for its choices, in the level of disagreement (insofar as this is disclosed by separate opinions) and in possible explanations that follow from the nature of the cases in which a certain approach is typically taken. Having discussed these general positions in the Court's case law, Section 4 concludes by offering an evaluative assessment of the Court's approach in light of its double role in the ECHR system.

23 This analysis has been made first by searching the present author's case law database for relevant judgments and decisions. This database consists of summaries of over 2,000 judgments and decisions for which the Court has either provided a separate press release or that have been given importance level 2 or higher; both factors are indicative of a certain perceived degree of general or legal relevance of a judgment or decision by the Court or its registry. Over time, consistent wording has been used in drafting the summaries, which provides for a type of coding that can be used for qualitative case law analyses. It allows, for example, for a search for terms like 'abstract', 'concrete', 'blanket', 'bright-line' or 'legislation'. Based on those searches, a sample of about 100 judgments and decisions have qualified as relevant to the present study. 

in abstracto?

\subsection{Direct Review of Legislation and the Victim Requirement}

In cases where legislation has allegedly caused a violation of the Convention, the first question to arise is whether the Court is competent to review the reasonableness of such legislation. At first glance, given the Court's case law on the admissibility requirements of Article $34 \mathrm{ECHR}$, it might be expected that it does not have such competence. ${ }^{24}$ The mere existence of legislation that affects a Convention right is not enough for a case to be admissible. ${ }^{25}$ Were this to be different, this could have the effect of allowing for an actio popularis to be brought, which is not accepted in the Convention system. ${ }^{26}$ This is shown, for example, by the cases of Ligue de musulmans de Suisse and Others $v$ Switzerland and Ouardiriv Switzerland, where the applicants complained about the introduction of a constitutional provision prohibiting the building of minarets. ${ }^{27}$ They claimed that the provision would violate their freedom of religion of Article 9 ECHR, but the Court observed that the provision had not yet begun to be implemented and it had no practical effect on the applicants. It further emphasised that the mere possibility that the legislation at some unspecified time in the future might be applied was not sufficient to show that the applicants' freedom of religion was specifically affected. In fact, the Court held, the applicants were trying to have the compatibility of the constitutional provision with the Convention reviewed in abstracto, whereas the Convention does not allow for such review.

It follows from this that legislation can only be an object of the Court's review if applicants are directly affected by it. ${ }^{28}$ In addition, the Court has held that applicants should have a valid personal interest which distinguishes them

24 See further, the Practical Guide on Admissibility Criteria (Strasbourg, Council of Europe, 2019) 10.

25 Cf Tulkens (n 22) 33.

26 See eg Roman Zakharov v Russia App no 47143/o6 (ECtHR, 4 December 2015), para 164; Centre for Legal Resources on behalf of Valentin Câmpeanu v Romania App no 47848/08 (ECtHR, 17 July 2014), para 101. See further, eg LA Sicilianos and MA Kostopoulou, The Individual Application under the European Convention on Human Rights. Procedural Guide (Strasbourg, Council of Europe, 2019) 59; Practical Guide on Admissibility Criteria (n 24) para 30.

27 Ligue des musulmans de Suisse and Others $v$ Switzerland App no 66274/og (ECtHR, 28 June 2011) and Ouardiriv Switzerland App no 65840/o9 (ECtHR, 28 June 2011).

28 See also Practical Guide on Admissibility Criteria (n 24) para 17. For an example of a case in which this requirement was met, see Aksuv Turkey App nos 4149/04 and 41029/04 (ECtHR, 15 March 2012), paras 51 and 53 . 
from all other persons that may be affected by the same legislation. ${ }^{29}$ This, too, can be a requirement that is difficult to meet if a complaint focusses on the reasonableness of legislation as such. For example, the Court has held that a legislative prohibition of the publication of opinion polls in the two weeks before parliamentary elections affected all voters in the same way. ${ }^{30}$ The applicants in this case, who had argued that the legislation interfered with their right to access to information, thus found themselves in the same position as everyone else did. For that reason, the Court decided not to admit their application.

This case law seems to limit the number of cases where the Court can directly and in abstracto review the reasonableness of legislation. Importantly, however, the Court has accepted several exceptions to this general rule of procedure. Most relevant to the present article is the exception made in cases where the requirement of being directly and personally affected would mean that an individual has to risk prosecution or suffer other disadvantages in order to trigger a concrete decision. ${ }^{31} \mathrm{~A}$ famous example of this exception is the $\mathrm{Dud}$ geon case, where the applicant had complained about legislation that criminalised homosexual conduct. ${ }^{32}$ Although Dudgeon himself had not (yet) been subjected to criminal prosecution, the Court agreed with him that the legislation as such should be the object of its review instead of its individual application, since the 'maintenance in force of the impugned legislation constitute[d] a continuing interference with the applicant's right to respect for his private life' and 'in the personal circumstances of the applicant, the very existence of this legislation continuously and directly affect[ed] his private life. ${ }^{33}$ The Court has often confirmed this stance, also in cases where the impact of the mere existence of legislative measures on the individual applicants was less substantial and less direct. ${ }^{34}$ Generally, for an application to be admissible, it suffices

29 Practical Guide on Admissibility Criteria (n 24) para 15; Sicilianos and Kostopoulou (n 26) at 59 .

$30 \quad$ Dimitras and Others $v$ Greece App nos 59573/og and 65211/og (ECtHR, 4 July 2017).

31 Exceptions to the victim rule are discussed only insofar as they are relevant to the concrete and abstract review of legislation. For different types of exception to the rules regarding direct victims, see eg Centre for Legal Resources on behalf of Valentin Câmpeanuv Romania App no 47848/08 (ECtHR, 17 July 2014) and the exceptions regarding secret surveillance; see further on this, in particular Practical Guide on Admissibility Criteria (n 24) paras zoff.

32 Dudgeon v the United Kingdom App no 7525/76 (ECtHR, 22 October 1981).

33 Ibid para 41.

34 See expressly Parrillo v Italy App no 46470/11 (ECtHR, 27 August 2015), para 111. See further eg SAS v France App no 43835/11 (ECtHR, 1 July 2014), para 110. See also Practical Guide on Admissibility Criteria (n 24) para 34. 
for an applicant to show reasonable and convincing evidence that the legislation has 'an impact on the applicant's (private) life' that continuously affects him, or that the applicant 'runs a risk of being directly prejudiced by the measure complained of, ${ }^{35}$ The Court can then focus its attention on the contested legislation and assess its compatibility with the Convention.

\subsection{Indirect Review of Legislation Underlying Individual Decisions}

In the cases discussed in section 2.1, the Court can directly review legislation, but such cases are relatively rare. Another situation occurs much more frequently, which is that of indirect reasonableness review of legislation. That situation arises when an individual decision has been made on the domestic level, for instance by an administrative body or a court or tribunal, which follows from a (discretionary or non-discretionary) application of legislation. In those cases, it can be the individual decision that affects the applicant's Convention rights, for example because the legislation has been applied in an arbitrary manner or because the rights and interests in the individual case have not been fairly balanced. In other cases, however, the legislation underlying the individual decision may be the actual cause of an interference with Convention rights. ${ }^{36}$ In those cases it can be necessary for the Court to conduct a review of the underlying legislation as well as (or instead of) the individual decision. It is in this type of cases that the question as to how the Court approaches its object of review arises most often, as is further explained in Section 3.

\section{Abstract and Concrete Review in the Court's Case Law}

In cases concerning direct review of legislation (discussed in Section 2.1), it is clear that the Court's object of review will be the legislation as such. Its review is then necessarily abstract in nature. In cases concerning indirect review of

35 See, respectively, Parrillo (n 34), para 112 and Kosaité-Čypiene and Others v Lithuania App no 69489/12 (ECtHR, 4 June 2019), para 7o. See similarly eg Ali Gürbüz v Turkey App no 52497/08 (ECtHR, 12 March 2019), paras 60-9, where the Court held that a continuing 'chilling effect' for the freedom of expression resulted from a widely drafted criminal law provision that prohibited certain expressions; this chilling effect constituted an interference with Article 10 ECHR in the individual case, even though the applicant had never been convicted for the violation of the domestic legislation. See also Practical Guide on Admissibility Criteria (n 24) para 31.

36 For one example out of many, see eg Stamose v Bulgaria App no 29713/05 (ECtHR, 27 November 2012), paras 34ff. For further discussion of this type of cases, see below, Section 3.3. 
legislation (discussed in Section 2.2), the Court's assessment can logically and theoretically take any of four forms: ${ }^{37}$

1) the Court can review only the individual application of legislation (purely concrete review);

2) the Court can first review the underlying legislation and decide that this is compatible with the Convention, and then assess whether the individual application violated the Convention (two-step approach);

3) the Court can review only the underlying legislation and conclude whether there is a violation of the Convention on that basis only (purely abstract review);

4) the Court can opt for a hybrid approach, meaning that it mixes elements of concrete and abstract review.

The systemic analysis made for the purposes of the present article shows that examples of all four approaches can be identified in the Court's case law, as is shown in the subsequent sections.

\subsection{Purely Concrete Review}

In a long line of case law, the Convention bodies have held that purely concrete review is the preferable option; in principle, abstract review of the underlying legislation is neither needed nor desirable. ${ }^{38}$ For example, the former European Commission of Human Rights took as its starting point in a 1976 decision that:

...the Commission is competent to examine the compatibility of domestic legislation with the Convention only with respect to its application in a concrete case, while it is not competent to examine in abstracto its compatibility with the Convention. ${ }^{39}$

The present Court's Grand Chamber repeated this in Perinçek $v$ Switzerland, where the applicant had complained about his conviction for making a statement in public to the effect that there had not been an Armenian genocide. ${ }^{40}$ This conviction was based on a provision of the Swiss Criminal Code, Article 261 bis (4), which stated that any person who sought to justify a genocide or other crimes against humanity would be punishable by a custodial sentence

$37 \quad$ Cf Gerards (n 12) 32 ff.

38 See also Tulkens (n 22) 33-4.

$39 X v$ Austria App no 7045/75 (EComHR, 10 December 1976), at 88, referring to a Commission decision of 1961.

40 Perinçekv Switzerland App no 27510/08 (ECtHR, 15 October 2015). 
or a fine..$^{41}$ The Court held that it would be best to restrict itself to a concrete review of the individual application of this provision:

In the present case, the Court is not required to determine whether the criminalisation of the denial of genocides or other historical facts may in principle be justified. Unlike the constitutional courts of France and Spain, which were entitled to - and indeed duty-bound - to examine the legislative provisions in this respect in the abstract ..., in a case which has its origin in an individual application the Court is constrained by the facts of the case .... It can thus only review whether or not the application of Article 261 bis $\S 4$ of the Swiss Criminal Code in the case of the applicant was 'necessary in a democratic society' within the meaning of Article $10 \S 2$ of the Convention.... ${ }^{42}$

Many judgments show that this purely concrete approach continues to be favoured by the Court. ${ }^{43}$ To give one example out of many, the case of $D L v B u l-$ garia concerned the placement of a minor in a correctional boarding school. ${ }^{44}$ Although the Court noted in its judgment that several points of criticism could be raised regarding the underlying educational and support system, it emphasised that 'its task is not to conduct an abstract examination, from the standpoint of the Convention, of the Bulgarian system of educational measures for minors, but to review the manner in which the existing system was applied in this particular case. ${ }^{45}$ It also noted that it did

not consider itself to have jurisdiction to examine the possible failings of the national system any further, seeing that it has been able to establish from the evidence before it that the measure to which the applicant was subjected pursued an educational purpose on a sufficient scale to fall within Article $5 \S 1$ (d) of the Convention. ${ }^{46}$

\footnotetext{
$41 \quad$ Ibid para 32.

42 Ibid para 226.

43 See more recently, eg Paradiso and Campanelli $v$ Italy App no 25358/12 (ECtHR, 24 January 2017), para 180; Pojatina v Croatia App no 18568/12 (ECtHR, 4 October 2018), para 78; Magyar Kétfarkú Kutya Párt v Hungary App no 201/17 (ECtHR, 21 January 2020), para 96.

$44 \quad$ DL $v$ Bulgaria App no 7472/14 (ECtHR, 19 May 2016).

45 Ibid para 76.

$46 \quad$ Ibid para 77 .
} 
These examples show that in the Court's perspective, the proper object of its review is the individual case at hand, which means that it should primarily conduct a concrete type of review. ${ }^{47}$ The principled reason it has provided for this is that its jurisdiction is limited to reviewing the compatibility of national acts or omissions with the Convention in individual cases.

\subsection{Two-Step Approach: First Abstract, then Concrete Review}

Regardless of the Court's well-established view that it should review the application of legislation in the particular case, there are numerous cases in which the Court does review the underlying measures in abstracto. In some cases, it thereby takes a two-step approach, which means that an abstract review of the legislation is followed by an assessment of the application in the individual circumstances of the case. ${ }^{48}$ This two-step approach is almost equally well-established in the Court's case law as the purely concrete approach. Already in 1979, the Court explained this in the following terms in Sunday Times $v$ the United Kingdom: ${ }^{49}$

...the Court's supervision under Article 10 covers not only the basic legislation but also the decision applying it .... It is not sufficient that the interference involved belongs to that class of the exceptions listed in Article 10 (2) which has been invoked; neither is it sufficient that the interference was imposed because its subject-matter fell within a particular category or was caught by a legal rule formulated in general or absolute terms: the Court has to be satisfied that the interference was necessary having regard to the facts and circumstances prevailing in the specific case before it. ${ }^{50}$

The Court thus made clear that its focus certainly should be the individual circumstances of the case, but also that its supervision could cover 'the basic legislation' underlying that decision.

A more concrete and recent example of the two-step approach can be seen in the Court's Grand Chamber judgment in Garibv the Netherlands. ${ }^{51}$ The basis for that case was constituted by legislation introduced in the Netherlands to

47 It can be noted, however, that in a case like $D L$ the Court paid at least some attention to the overall reasonableness and fairness of the underlying legislation.

48 See also Gerards ( $\mathrm{n} 12) 33$.

49 Sunday Times v the United Kingdom (No 1) App no 6538/74 (ECtHR, 26 April 1979). See also Gerards (n 12) 33 .

5o Ibid para 65.

$5^{1}$ Garibv the Netherlands App no 43494/o9 (ECtHR, 6 November 2017). 
improve social cohesion and reduce crime in certain city neighbourhoods. The legislation allowed municipalities to use a system of housing permits in designated areas. Such housing permits could only be obtained by new residents if they met certain income conditions. The applicant had applied for a housing permit to live in a particular neighbourhood of Rotterdam, but this was refused because she did not meet the income requirements. She complained to the Court that this constituted a violation of her right to freely choose her residence as protected by Article 4 of Protocol No. 2 ECHR. In its judgment, the Court focussed on 'the legislative and policy background of the case' first. ${ }^{52}$ Based on extensive reasoning it concluded in general terms that it could not 'find that the policy decisions taken by the domestic authorities fail[ed] to make adequate provision for the rights and interests of persons in the applicant's position'.53 Only then the Court turned 'to the circumstances of the applicant herself. ${ }^{54}$ Based on an assessment of her particular situation, it held that it was not established that 'the consequences for the applicant of the refusal to her of a housing permit that would have allowed her to move to the B. Street dwelling amounted to such disproportionate hardship that her interest should outweigh the general interest served by the consistent application of the measure in issue. ${ }^{55}$ Clearly, thus, the Court first reviewed the reasonableness of the legislation as a whole, and only then focussed on its application in the individual case.

The type of two-step approach that can be seen in Garib is not only applied in cases where the Court finds that the legislation is compatible with the Convention, but also in some cases where the Court holds that the legislation or national practice was flawed. In those cases, the Court's reasoning is that regardless of the abstract defects in the legislation, these were not such as to give rise to a violation of a Convention right in the individual case. Such an approach can be observed in the case of Goranova-Karanaeva $v$ Bulgaria. ${ }^{56}$ The applicant in this case had complained of a breach of her privacy rights under Article 8 ECHR because listening devices had secretly been installed in her

\footnotetext{
$52 \quad$ Ibid para 142.

53 Ibid para 156 .

54 Ibid para 158.

55 Ibid para 165. For a similar approach (but with a finding of a violation in the individual case), see eg Aktaş and Aslaniskender v Turkey App no 18684/07 (ECtHR, 25 June 2019), paras 45-6 (abstract review) and 47-48 (concrete (procedural) review) (see also the concurring opinion of Judge Lemmens to this case, who argued that in this case, the legislation as such was already flawed); Wolter and Sarfert $v$ Germany App nos 59752/13 and 66277/13 (ECtHR, 23 March 2017), paras 71 (abstract review) and 72-80 (concrete).

Goranova-Karanaeva v Bulgaria App no 12739/05 (ECtHR, 8 March 2011).
} 
office. The Court noted that in earlier cases, it had found that, 'Bulgarian law governing secret surveillance partly met and partly failed to meet' the Convention requirements, and it recalled a series of deficiencies it had identified in those cases. ${ }^{57}$ However, the negative outcome of this abstract review of the applicable legislation was not enough for the Court to reach a conclusion as to whether there was a violation of the Convention. Instead, it recalled that ' $[\mathrm{i}] \mathrm{n}$ cases arising from individual applications, the Court must as a rule focus its attention not on the law as such but on the manner in which it was applied to the applicant in the particular circumstances'.58 It therefore continued to assess the facts and circumstances of the applicant's individual case, noting that there were differences between the 'archetypical situation' that had given rise to its earlier criticism of the legislative system and the facts of the present case ${ }^{59}$ It concluded that the interference was justified as 'necessary in a democratic society', and that there was therefore no violation of the Convention. ${ }^{60}$

The Court usually does not provide any specific reasons for adopting such a two-step approach, but it did do so in the case of Lukats $v$ Romania. ${ }^{61}$ This case concerned the applicant's inability to secure compensation for a loss of possessions that she had been entitled to according to a legislative compensation scheme. The Court held that it clearly should decide whether the lack of payment of compensation placed an excessive burden on her, ${ }^{62}$ but that it was important that 'the applicant's claims should also be looked at from a more general perspective', since 'the obligation to compensate, undertaken by the Romanian State under various international treaties or via specific domestic legal provisions ... concerned not only the applicant, but also many other Romanian citizens'. ${ }^{63}$ For that reason the Court considered it 'necessary to examine the case also from the perspective of the general measures that were taken in the interest of other potentially affected individuals'. ${ }^{64}$ Thus, in the

$57 \quad$ Ibid para 47.

$5^{8} \quad$ Ibid para 48.

59 Ibid para 50.

$60 \quad$ Ibid paras $5{ }^{2-3}$. For a similar approach, see eg Famulyak v Ukraine App no 30180/11 (ECtHR, 26 March 2019). In the different context of prison conditions and minimum personal floor space, the Court has adopted a general standard that may not be met by the national authorities in all cases, but it has also emphasised that the strong presumption of an Article 3 violation can be rebutted depending on the circumstances of the individual case; see Muršić v Croatia App no 7334/13 (ECtHR, 20 October 2016), paras 126 and $136-41$.

$61 \quad$ Lukats v Romania App no 24199/o7 (ECtHR, 5 April 2016).

62 Ibid para 50.

63 Ibid.

64 Ibid. 
Court's perspective, adding a more abstract review to a purely concrete test can serve the interests of having a well-balanced and fair review in the individual case, as well as help it to offer general justice and identify more structural issues that could be of relevance beyond the facts of the concrete case.

Regardless of such advantages, the use of a two-step approach is debated within the Court. This is shown in particular by the joint dissenting opinion of Judges Tsotsoria and De Gaetano in the Garib case discussed above. ${ }^{65}$ In these judges' view, 'the Court must confine its attention to the concrete case before it', and it should not look into the overall reasonableness of the legislative system. ${ }^{66}$ Similarly, Judge Pinto de Albuquerque, joined by Judge Vehabović, argued in a dissenting opinion to the Garib case that 'the Convention must necessarily be read in a pro persona perspective, placing the individual at the heart of the reasoning', and the Court should focus its review 'on the particular effects of the individual measure sustained by [the applicant]. ${ }^{67}$ The reason for this was that 'the Court's mission consists in securing the effective enjoyment of Convention rights at an individual level. ${ }^{68}$ Even though Judge Pinto de Albuquerque admitted that this objective could also be realised by allowing an abstract review followed by an adequate individualised assessment, he thus favoured a purely concrete review. ${ }^{69}$

Finally, it is interesting to see that such criticism is hardly voiced in cases where the Court has formulated general positive obligations for the Convention States to establish a proper legal and administrative framework to deal with particular issues. It has done so in particular in relation to the prevention of harm to individuals' lives or health, domestic or discriminatory violence, human trafficking or exploitation, and child abduction. ${ }^{70}$ In such cases the

65 Garib v the Netherlands App no 43494/o9 (ECtHR, 6 November 2017).

66 Ibid joint dissenting opinion of Judges Tsotsoria and De Gaetano, para 3.

67 Ibid dissenting opinion of Judge Pinto de Albuquerque, joined by Judge Vehabović, paras $11-2$.

68 Ibid dissenting opinion of Judge Pinto de Albuquerque, joined by Judge Vehabović, para 14.

69 The dissenting Judges put it more strongly: '... [T] he scrutiny of the interference sustained by Ms Garib must not be exercised exclusively or principally at the level of the general measure regulating housing permits for deprived neighbourhoods ... but also and above all must also concern the individual measure by which the applicant was denied such a permit' (Garib, Dissenting opinion of Judge Pinto de Albuquerque, joined by Judge Vehabović, para 14).

70 See eg, regarding domestic and discriminatory violence, $A$ and $B v$ Croatia ECtHR, 20 June 2019, 7144/15), para 120 (abstract review) and paras 121ff (concrete review); Alković $v$ Montenegro App no 66895/10 (ECtHR, 5 December 2017), para 68 (abstract review) and 69-73 (concrete review); Valiulienè $v$ Lithuania App no 33234/o7 (ECtHR, 26 March 2013), para 78 (abstract review) and paras 8 off (concrete review); in relation to procedural positive 
Court tends to review first whether the State has generally met its legislative positive obligations, and only then look into the facts of the individual case to see if there was a concrete violation of the Convention. ${ }^{71}$ Moreover, just as for the other two-step approach cases, the Court has emphasised in procedural positive obligations cases that it also should apply a concrete review if it has already established that the national legislative system is generally flawed. For example, in Lopes de Sousa Fernandes $v$ Portugal, it held that 'the mere fact that the regulatory framework may be deficient in some respect is not sufficient in itself to raise an issue under Article 2 of the Convention. It must be shown to have operated to the patient's detriment. ${ }^{72}$ Thus, the Court's position in positive obligations cases appears to be that it is not possible to conflate the two types of review and derive from the lack of overall reasonableness of a legislative system that the Convention has also been violated in the individual case. Even though the Court has not really offered any concrete reasons for this, it clearly considers it important to assess if the State met its positive obligations in the abstract separately from its examination if this resulted in a violation in the specific case. The absence of separate opinions arguing that a purely concrete approach also should be adopted in relation to procedural positive obligations seems to confirm that this is hardly controversial within the Court.

\subsection{Purely Abstract Review}

\subsubsection{Direct Review of Legislation}

It has been shown in the above that the Court usually finds that 'the question whether there has been a failure by the State in its regulatory duties calls for a concrete assessment of the alleged deficiencies rather than an abstract one.73 Nevertheless, in some cases the Court chooses to conduct a purely abstract

obligations under Articles 2/3/4 ECHR, see eg TI and Others $v$ Greece App no 40311/10 (ECtHR, 18 July 2019), para 145 (no need to look into the individual application since abstract review disclosed that the legislative framework was flawed); Altuğ and Others $v$ Turkey App no 32086/o7 (ECtHR, 30 June 2015), paras 73 (abstract) and 85 (concrete); and in relation to child abduction, Hromadka and Hromadkova $v$ Russia App no 22909/10 (ECtHR, 11 December 2014), paras 170 (abstract) and 171-2 (concrete).

71 The Court does not necessarily always look into the concrete facts of the case. In Soares Campos $v$ Portugal App no 30878/16 (ECtHR, 14 January 2020), for example, it generally reviewed the regulatory system in place in relation to responsibility for hazing incidents, without examining their application in the concrete case (see paras 168-72).

$72 \quad$ Lopes de Sousa Fernandes v Portugal App no 56080/13 (ECtHR, 19 December 2017), para 188. For another example, see Volodina $v$ Russia App no 41261/17 (ECtHR, 9 July 2019), paras $78 \mathrm{ff}$ (abstract review) and paras goff (concrete review).

73 Lopes de Sousa Fernandes v Portugal App no 56080/13 (ECtHR, 19 December 2017), para 188. 
review, and it will be shown in this subsection that this choice is informed by a variety of reasons. Most often, purely abstract review stems from the Court's choice to conduct a direct review of legislation, as it did in the Dudgeon case discussed in Section 2. The complaint in Dudgeon related to legislation that criminalised homosexual conduct and the Court held that the very existence of that legislation constituted an interference with his private life. ${ }^{74}$ The Court then focussed its assessment of reasonableness on the contested legislation to conclude that the reasons given by the Government were 'not sufficient to justify the maintenance in force of the impugned legislation in so far as it has the general effect of criminalising private homosexual relations between adult males capable of valid consent'. ${ }^{75} \mathrm{~A}$ more recent example of this approach can be seen in the case of $S A S v$ France, which concerned a blanket legislative ban on wearing a full-face veil. ${ }^{76}$ The applicant had not been subjected to any concrete sanction for violating the legislation, but the Court held that she was confronted with a dilemma comparable to that which the Court identified in the Dudgeon case: either she had to comply with the ban and thus refrain from dressing in accordance with her approach to religion, or she would refuse to comply and face prosecution. ${ }^{77}$ The Court then continued to review the legislation as such and accepted in general terms that it did not constitute a violation of the Convention as it was sufficiently justified. ${ }^{78}$ Since no individual decision had been made in the case on the national level that it could use as a concrete object of review, this conclusion was not followed by any individualised form of reasoning.

\subsubsection{Infringement of Fundamental Rule of Law Values}

The Court may also opt for a purely abstract review in other types of cases. One first category comprises cases where fundamental rule of law values are at stake, in particular cases on the right to a fair trial and access to court of Article 6 ECHR. ${ }^{79}$ An example can be seen in the Chamber judgment in the case of

\section{Dudgeon (n 32$)$.}

75 Ibid para 61.

76 SAS v France App no 43835/11 (ECtHR, 1 July 2014), paras 157-9.

77 Ibid para 57.

78 See similarly, eg Belcacemi and Oussar v Belgium App no 37798/13 (ECtHR, 11 July 2017), paras 50-63; Khaktokhu and Aksenchik v Russia App nos 60367/08 and 961/11 (ECtHR, 24 January 2017), para 87 .

79 See, in particular, also Mustafa Tunç and Fecire Tunçv Turkey App no 24014/05 (ECtHR, 14 April 2015), where the Grand Chamber expressly contrasted the procedural obligations following from Articles 2 and $6 \mathrm{ECHR}$; it emphasised that whereas Article 6 asks for an abstract assessment (para 221), 'the requirements of Article 2 call for a concrete examination 
Guðmundur Andri Ástráđsson v Iceland. ${ }^{80}$ The case concerned legislation setting procedural rules and requirements for the establishment of a new appeals court in Iceland. The applicant himself had been convicted by the appeals court for drunk driving without a licence. He argued that his conviction should be considered contrary to the Convention because the appeals court had not been established in accordance with the domestic legislation, due to demonstrable flaws in the application of the new legislation when the appeals court was established. The respondent Government contended that the problems that had tainted the newly-established appeals court did not affect the applicant's individual situation and he had been given a fair trial. Thus, whilst the applicant proposed to deal with the case in abstracto, the Government argued in favour of concrete review. The Court's Chamber chose to follow the applicant's line of reasoning, emphasising that 'the requirement that a tribunal be established by law is closely connected to the other general requirements of Article $6 \S 1$, on the independence and impartiality of the judiciary, both also being an integral part of the fundamental principle of the rule of law in a democratic society' ${ }^{81}$ According to the Court it followed from this that:

a violation of this principle, like the principles under the same provision that a tribunal shall be independent and impartial, does not require a separate examination of whether the breach of the principle that a tribunal be established by law rendered a trial unfair. ${ }^{82}$

It was therefore of no relevance to the outcome of the case if the procedural defects actually affected the fairness of the applicant's trial or led to any other individual disadvantage. ${ }^{83}$

of the independence of the investigation in its entirety, rather than an abstract assessment' (para 222).

8o Guðmundur Andri Ástráðsson v Iceland App no 26374/18 (ECtHR, 12 March 2019). It should be emphasised that at the time of writing, this case was pending before the Court's Grand Chamber.

81 Ibid, para 99.

82 Ibid, para 100.

83 See similarly, eg Ali Rizaand Others v Turkey App no 30226/10 (ECtHR, 28 January 2020), paras 194-223. A different approach is possible, as is illustrated by the approach the European Court of Justice (ECJ) took in LM (defects in judicial procedures), ECJ 25 July 2018, Case C-216/18 PPU, ECLI: EU: C: 2018: 586, paras 74-6; the ECJ held that a two-step approach should be taken in cases concerning systemic risks to the independence of courts, which implied that the national court should always also examine whether any systematic risks would lead to a flagrant denial of the right to a fair trial in the concrete case. 


\subsubsection{Bright-line Rules and Blanket Legislation}

The Court further can be seen to apply a purely abstract review in cases where the complaint focusses on an individual decision, but there was (very) little discretion for the national authorities to deviate from the underlying legislation. This may occur if the national legislation provides for blanket or brightline rules or for binding legislative presumptions. Usually the Court objects to such legislation; it prefers legislative systems that allow for individualised balancing on the national level. ${ }^{84}$ Indeed, if a blanket ban has the result of fully depriving a certain group (such as prisoners or adoptive mothers) from the possibility to enjoy a Convention right, the Court may choose to apply a direct review of legislation and it may find a violation of the Convention without seeing a need to look into the facts of the individual case. ${ }^{85}$ Nevertheless, the Court sometimes accepts blanket rules if it is convinced that they are the best possible way to solve particularly difficult matters and create legal certainty, and it may then refuse to look into the way they have been applied in a specific case. ${ }^{86}$ An example of such a situation can be seen in the Evans case. ${ }^{87}$ The applicant was a woman who could only give birth to a child genetically related to her if a fertilised ova would be placed in uterus. The ova had been fertilised by her partner, but after their separation, he had refused to give consent for their

84 Eg Saber and Boughassal $v$ Spain App nos 76550/13 and 45938/14 (ECtHR, 18 December 2018), paras 46-8; Sõro v Estonia App no 22588/o8 (ECtHR, 3 September 2015), paras 60-4; Nusret Yaka and Others $v$ Turkey App no 43750/o6 (ECtHR, 22 April 2014), para 59; Stamose $v$ Bulgaria App no 29713/05 (ECtHR, 27 November 2012), paras 34ff; MD and Others $v$ Malta App no 64791/10 (ECtHR, 17 July 2012), para 79. See also, in particular, the judgments on disenfranchisement of prisoners, where the Court regularly requires some degree of individualisation; eg Kulinski and Sabev v Bulgaria App no 63849/og (ECtHR, 21 July 2016), paras 37ff; Scoppola v Italy (No 3) App no 126/05 (ECtHR, 22 May 2012), para 108.

85 On the right of prisoners to vote, see eg Kulinski and Sabev v Bulgaria App no 63849/o9 (ECtHR, 21 July 2016), para 42. For another example, where the prison regime for male prisoners contained many more restrictions on their rights than did the regime for female prisoners, see Écis $v$ Latvia App no 12879/o9 (ECtHR, 10 January 2019), paras 82-93. See similarly also Chaldayev v Russia App no 33172/16 (ECtHR, 28 May 2019), paras 77-83. For an example of an abstract review of a legislative difference between adoptive and biological mothers, see Topčić-Rosenberg v Croatia App no 19391/11 (ECtHR, 14 November 2013), paras 38-49. See further, eg Berkovich and Others $v$ Russia App no 5871/07 (ECtHR, 27 March 2018), paras 96-8 (although the Court did mix some more concrete elements into its review in this case to illustrate the burden created by the blanket rule, making its approach close to a hybrid; see further below, Section 3.4).

86 For the conditions under which the Court may accept such blanket legislation, see in particular Animal Defenders International v the United Kingdom App no 48876/o8 (ECtHR, 22 April 2013), paras 108-10. For a related rationale, see eg Vrzić v Croatia App no 43777/13 (ECtHR, 12 July 2016), paras 63-73.

87 Evans $v$ the United Kingdom App no 6339/05 (ECtHR, 10 April 2007). 
use. This created a dilemma: Either the applicant could not become a biological mother, or her ex-partner would be compelled to become a biological father. In this type of situation, the Court held, it may be acceptable to opt for general legislation that does not allow for individualised decision-making, since 'the absolute nature of the rule served to promote legal certainty and to avoid the problems of arbitrariness and inconsistency inherent in weighing, on a case-by-case basis, ... "entirely incommensurable" interests'. ${ }^{88}$ More generally, in Animal Defenders International, the Court accepted that legal certainty and equality can be good reasons for adopting a blanket rule that does not allow for (much) individualisation. ${ }^{89}$ In $X$. and Others $v$ Austria, the Court's Grand Chamber further made clear that in sensitive cases concerning blanket legislation, it may have no other choice available than that of reviewing the overall reasonableness of the legislation, since 'the blanket prohibition in issue, by its very nature, removes the factual circumstances of the case from the scope of both the domestic courts' and this Court's examination really ....90 The Grand Chamber also mentioned that this made 'any examination of the specific circumstances of their case unnecessary and irrelevant. ${ }^{91}$ Yet, even though this seemed to amount to a somewhat direct and abstract review of the Austrian legislation, the Court emphasised that it was 'not reviewing the law in abstracto'.92

In line with the rationale provided in these Grand Chamber judgments, in most cases on the individual application of blanket legislation, the Court embarks on fully abstract review without further ado. The Court then usually assesses the legislation for its reasonableness and proportionality and derives from this that the Convention was violated without looking into the specific circumstances of the individual case. A representative example of this approach can be found in Lashmankin and Others $v$ Russia, where the applicants had complained about a blanket statutory ban on holding public events in,

88 Ibid para 89. See also J Bomhoff and L Zucca, 'The Tragedy of Ms Evans: Conflicts and Incommensurability of Rights' (2006) 2 European Constitutional Law Review 429. See also, in a different context (voting rights), Shindlerv the United Kingdom App no 19840/og (ECtHR, 7 May 2013), para 116. For a different type of argumentation, which is more related to the separation of powers and the role of courts in this type of moral dilemma cases, see Nicklinson and Lamb v the United Kingdom App nos 2478/15 and 1787/15 (ECtHR, 23 June 2015), para 84 .

89 Animal Defenders International v the United Kingdom App no 48876/o8 (ECtHR, 22 April 2013), paras 108-10. See also, The National Union of Rail, Maritime and Transport Workers $v$ the United Kingdom App no 31045/10 (ECtHR, 8 April 2014), paras 101-4.

$90 \quad X$ and Others $v$ Austria App no 19010/07 (ECtHR, 19 February 2013), para 126.

$91 \quad$ Ibid.

$92 \quad$ Ibid. 
among others, the vicinity of court buildings. ${ }^{93}$ The Court examined in abstracto if the ban had been the subject of exacting parliamentary and judicial review, if a general ban was demonstrably a more feasible means than a provision allowing case-by-case examination, and if there would be a justification for such a general ban in a risk of significant uncertainty, discrimination or arbitrariness. ${ }^{94}$ It then continued to examine the substantive reasonableness of the legislation and concluded that it was incompatible with Article 11 of the Convention, without paying much attention to the consequences in the case at hand. ${ }^{95}$

Finally, even if the Court opts for general reasonableness review in most blanket legislation cases, it may still insert some elements of concrete review in its reasoning. In the Animal Defenders International case, for example, the Court first considered that it should look into whether the respondent State, by adopting blanket legislation on political advertising, had remained within the margin of appreciation afforded to it. ${ }^{96}$ In line with the abstract type of review it commonly applies in such cases, the Court listed a number of arguments relevant to its assessment of the overall reasonableness of the contested legislation and its blanket nature. ${ }^{97}$ As such, these could have sufficed to allow it to conclude that the legislation was compatible with the Convention and that, therefore, there was no violation of the Convention. However, the Court continued also to remark that 'the impact of the prohibition in the present case' could not warrant a different conclusion. ${ }^{98}$ To underpin this finding it listed a number of arguments showing that the position of the individual applicant had not been overly harmed by the application of the legislation, and it concluded from this that there had not been a disproportionate interference with the applicant's Convention rights. ${ }^{99}$ Thus, in the end, the Court applied a twostep approach rather than a purely abstract review, even though this was a clear case of review of blanket legislation. ${ }^{100}$ The reasons for this were not expressly stated in the Court's judgment.

93 Lashmankin and Others v Russia App no 57818/o9 (ECtHR, 7 February 2017).

94 Ibid para 436.

95 Ibid para 441; see similarly, Kablis v Russia App nos 48310/16 and 59663/17 (ECtHR, 30 April 2019), paras 52-9. For another example of this type, see Biao $v$ Denmark App no 38590/10 (ECtHR, 24 May 2016).

96 Animal Defenders International v the United Kingdom App no 48876/08 (ECtHR, 22 April 2013), para 110.

97 Ibid paras $113^{-23}$.

98 Ibid para 124 .

99 Ibid paras $124-5$.

100 The Grand Chamber's judgment has been criticised for this reason by eg Judge Bratza who, in his concurring opinion to the case, remarked that, '... there are many cases where 


\subsubsection{Reasonableness Review of Social Security Legislation}

Another line of case law shows that the Court tends to apply a purely abstract review in cases concerning alleged discrimination in social security legislation or cases on social benefits and economic issues. ${ }^{101}$ In such cases, it is common for the Court to use phrasing such as this, taken from its judgment in British Ghurkha Welfare Society:

The Court observes at the outset that, as with most if not all complaints of alleged discrimination in a welfare or pensions system, the issue before it for consideration goes to the compatibility of the system with Article 14, not to the individual facts or circumstances of the particular applicants or of others who are or might be affected by the legislation.... Rather, the Court's role is to determine the question of principle, namely whether the legislation as such unlawfully discriminates between persons who are in an analogous situation.... ${ }^{102}$

The Court's abstract review of such legislation thus mainly seems to be inspired by the nature of the legislation at stake, which makes it more appropriate to rely on a review of the reasonableness of the overall system than on a very strict probing into an individual decision.

In the Carson case, the Court added another reason for its general approach in these cases. ${ }^{103}$ The applicants had claimed that the amendment of a pension scheme led to extreme financial hardship in many cases. ${ }^{104}$ The Court emphasised at the outset that it was 'not in a position to make an assessment of the effects, if any, on the many thousands in the same position as the applicants

the Court has accepted the need for a 'brightline' or general statutory rule and has found no violation of the Convention even though loyalty to the rule may involve apparent hardship to the applicant in the individual case. In such a case, the answer to the question of compatibility is not and cannot be determined by reference to the particular circumstances of the applicant caught by the statutory provision in question' (Animal Defenders International, Concurring Opinion of Judge Bratza, para 4).

101 See eg, Twizell v the United Kingdom App no 25379/o2 (ECtHR, 20 May 2008); Maggio and Others $v$ Italy App nos 46286/og et al. (ECtHR, 31 May 2011). See also, eg, Vrzić v Croatia App no 43777/13 (ECtHR, 12 July 2016), paras 63-73. Importantly, in those cases, the private law nature of the underlying conflict may also play a role in the Court's decision to accept an exception to the general rule that individualised proportionality review is needed; see in particular FJM $v$ the United Kingdom App no 76202/16 (ECtHR, 6 November 2018), paras 41-3.

102 British Ghurka Welfare Society and Others $v$ the United Kingdom App no 44818/11 (ECtHR, 15 September 2016), para 63 .

103 Carson and Others $v$ the United Kingdom App no 42184/05 (ECtHR, 16 March 2010).

104 Ibid para 62. 
and nor should it try to do so'. In addition, it accepted that, 'any welfare system, to be workable, may have to use broad categorisations to distinguish between different groups in need'. For that reason, it chose to focus on the reasonableness and fairness of the legislative classifications as such, rather than the individual facts and circumstances of the case.

Finally, in the domain of social security and social benefits, purely abstract review can be found in some cases that do not concern bright-line rules, but legislation that allows for significant discretion on the national level. An example can be found in the Court's judgment in the 'bedroom tax' case (JD and $A v$ the United Kingdom) that was discussed in the introduction. ${ }^{105}$ The case concerned an amendment of housing benefits legislation in the United Kingdom to ensure that the level of the benefits received was in line with the number of rooms needed by the number of inhabitants of a house. In cases where this led to a reduction of the benefits received, persons could apply for discretionary housing payments (DHP) to meet the difference. These were awarded on a temporary basis, taking into account the circumstances of the case. In its reasoning regarding the complaints by applicant JD, the majority of the Court's Chamber chose to rely on a purely abstract type of review. It emphasised that the DHP scheme had a number of significant disadvantages and some advantages and that the awards of DHP were made subject to certain safeguards that would prevent them being awarded where they were not needed. ${ }^{106}$ Although the Court found that the DHP scheme could be characterised as not ensuring the same level of certainty and stability as the previous legislation offered, it held that, "its provision with attendant safeguards, amount[ed] to a sufficiently weighty reason to satisfy the Court that the means employed to implement the measure had a reasonable relationship of proportionality to its legitimate aim. ${ }^{\prime 107}$ Accordingly, it held that the difference in treatment identified in the case of JD was justified, without looking into the actual disadvantage that the applicant said she had suffered. ${ }^{108}$ Although the Court did not offer any concrete explanation for its choice to rely on a fully abstract review, it may well be that one can be found in the general considerations regarding social security cases that it has formulated in judgments such as those cited above.

105 JD and A $v$ the United Kingdom App nos 32949/17 and 34614/17 (ECtHR, 24 October 2019).

106 Ibid paras 101-2.

107 Ibid para 102.

108 Ibid para 102. For another example, see Manole and 'Romanian Farmers Direct' $v$ Romania App no 46551/o6 (ECtHR, 16 June 2015), paras 62-75. 


\subsection{Hybrids}

Finally, there are several cases in which the Court mixes the concrete and abstract approaches together in such a way that the result can only be typified as a hybrid form of review. ${ }^{109}$ An example can be seen in the Bayev case, which concerned the prohibition of public statements aimed at the promotion of homosexuality among minors (so-called 'homo propaganda') in various regions in Russia. ${ }^{110}$ Based on the relevant legislation, the applicants had been fined for, inter alia, holding banners in front of a school with texts such as, 'homosexuality is normal' or 'I am proud of my homosexuality'. The applicants in the case had not so much complained about these concrete fines, as well as about the very existence of the legislation on which the individual decisions were based. The Court - probably for that reason - decided to opt for a mixed approach:

The measures taken against the applicants were based on the legislative provisions specifically adopted to outlaw the promotion of homosexuality and non-traditional sexual relations among minors. ... The Court reiterates that, in order to determine the proportionality of a general measure, it must primarily assess the legislative choices underlying it, regard being had to the quality of the parliamentary and judicial review of the necessity of the measure, and the risk of abuse if a general measure were to be relaxed. In doing so it will take into account its implementation in the applicants' concrete cases, which is illustrative of its impact in practice and is thus material to the measure's proportionality....'111

The hybridity of its approach is also witnessed by the Court's conclusion:

In the light of the above considerations the Court finds that the legal provisions in question do not serve to advance the legitimate aim of the protection of morals, and that such measures are likely to be counterproductive in achieving the declared legitimate aims of the protection of health and the protection of rights of others. Given the vagueness of the terminology used and the potentially unlimited scope of their application, these provisions are open to abuse in individual cases, as evidenced in the three applications at hand. Above all, by adopting such laws the

109 Gerards (n 12) 35.

110 Bayev and Others $v$ Russia App no 67667/og (ECtHR, 20 June 2017).

111 Ibid para 63. See similarly in Novikova and Others $v$ Russia App no 25501/o7 (ECtHR, 26 April 2016), para 194; Ognevenko v Russia App no 44873/og (ECtHR, 20 November 2018), para 69 . 
authorities reinforce stigma and prejudice and encourage homophobia, which is incompatible with the notions of equality, pluralism and tolerance inherent in a democratic society. The foregoing considerations are sufficient to enable the Court to conclude that in adopting the various general measures in question and by implementing them in the applicants' cases the Russian authorities overstepped the margin of appreciation afforded by Article 10 of the Convention. Accordingly, there has been a violation of this provision.'112

These considerations show that the Court, in the end, was just as much concerned with the individual applicants and the harm they suffered as a result of an interference with a Convention right as with the substantive incompatibility of the underlying legislation with the Convention. ${ }^{113}$

Other hybrids may also occur. In particular, the Court's overall review of the legislative system may form part of its assessment of the importance of the general interest of upholding that system in the individual case. In that situation, the abstract review of the legislation forms a part of the review of the proportionality and necessity of the individual interference. An example of such a hybrid can be seen in Zelenchuk and Tsytsyura $v$ Ukraine. ${ }^{114}$ The applicants in the case had inherited shares of farmland, which they had then rented out to commercial companies. Due to a 'land moratorium' it was prohibited to alienate or change the designated use of the land. In order to determine if the applicants' property rights under Article 1 ECHR were violated by the moratorium, the Court first investigated the overall necessity of relying on a temporary blanket ban and it criticised the national authorities for not having properly identified any alternative measures. It then found that the lack of any necessity for the blanket rule to be upheld had a substantial weight in the

\footnotetext{
112 Bayev (n 110) paras 83-4.

113 For a similar approach, see eg Dubská and Krejzováv the Czech Republic App nos 28859/11 and 28473/12 (ECtHR, 15 November 2016), paras 18off, where the Court noted that it had to examine, 'whether or not the respondent State, by introducing legislation that did not allow in practice for such assistance [ie, assistance with home births, author], overstepped the margin of appreciation afforded to it' (para 180), which is indicative of abstract review, but it also mentioned that it should confine itself, 'without overlooking the general context, to examining the issues raised by the case before it' (para 184). This combination did not lead to a clear two-step approach (although such an approach can be seen in the dissenting opinion of Judges Sajó, Karakaş, Nicolaou, Laffranque and Keller), but to a mixture of considerations regarding the system as a whole and its consequences for the individual applicants.

114 Zelenchuk and Tsytsyura v Ukraine App nos 846/16 and 1075/16 (ECtHR, 22 May 2018).
} 
assessment of the proportionality in the individual case, ${ }^{115}$ which formed an important argument for the Court to establish that the applicants were made to bear an excessive burden. ${ }^{116}$ Hence, elements of abstract and concrete review were mixed together, allowing the Court to assess both the overall reasonableness of the legislative system and of the application in the individual case before it. ${ }^{117}$

\subsection{Summary and Evaluation}

The preceding sections have demonstrated that there is a considerable variety in the Court's choice of the object of its reasonableness review. As a matter of principle and as its default position, the Court aims to restrict its review to the concrete circumstances of an individual case. Indeed, even in some cases of seemingly purely abstract review the Court has pointed out that concrete and abstract review were in fact conflated and the Court's findings relating to the (un)reasonableness of the legislation necessarily and automatically dictated its findings as to the individual case. Similarly, it can be argued that in the hybrid category of cases and the two-step approach cases, the Court's reasoning comes down to concrete review, since it always takes account of the particular circumstances of the case next to or in addition to the legislation as such.

Nevertheless, it is equally clear that in many cases, the Court has considered itself competent to review legislation in abstracto, without looking into the particular facts of a case. This happens most often in cases where the Court has to review blanket legislation or bright line rules, which have been adopted on the national level to ensure legal certainty and equality or solve moral dilemmas. In addition, the Court may adopt a purely abstract review in cases where protection of the rule of law is a central issue. As a matter of principle, it may then find a violation of the Convention if it finds that the rule of law has been breached, regardless of the fact that the individual applicant has suffered no, or only limited, harm. Finally, there are several cases related to social security and social benefits, as well as other cases related to economic rights, where the

\footnotetext{
115 Ibid para 130.

116 Ibid para 144.

117 Similarly, in Ognevenko v Russia, the Court took the existence of a blanket ban and the justification for that ban into account as an element in its overall proportionality review in the individual case (App no 44873/og, ECtHR, 20 November 2018), paras 73-84). Also in other cases the Court does not strictly distinguish the abstract and concrete elements of its review, as it would do in a two-step test, but the judgment still contains elements that make clear that it has reviewed both the legislation as a whole (or the lack of appropriate legislation) and the consequences of that (lack of) legislation for the case before it; see eg MG v Turkey App no 646/10 (ECtHR, 22 March 2016); Statileo v Croatia App no 12027/10 (ECtHR, 10 July 2014).
} 
Court prefers to rely on an overall review of the reasonableness of legislation. It may choose to do so because of the discretion it usually leaves in such cases to the national legislature, which would not sit easily with close review of individual decisions. Another stated reason for this is related to the Court's limited capacity to deal with the many concrete cases that can stem from such broad legislation.

It would be overly simplifying matters, however, to conclude that the Court's 'system' of abstract and concrete review comes down to a general rule (concrete review) with some exceptions (abstract review). In fact, the analysis presented above has disclosed many in-between or confused cases. It is not always easy to predict if the Court will only look into the facts and circumstances of the case or also into the underlying legislation. Indeed, in some cases where the Court has applied an abstract review of legislation, it could have restricted itself just as easily to an examination of the concrete case. One can think here of the Dutch housing permit case, Garib, where the dissenters expressly questioned the need for the Court to look into the overall reasonableness of the legislative system.

In addition, although the Court will often continue its assessment of a case after it has found that the overall legislative system is compatible or incompatible with the Convention, doing so is certainly not automatic. This is illustrated by the judgment in $J D$ and $A$, the bedroom tax case, in which the Court applied a purely abstract review in a case concerning a legislative system that left much discretion to the national authorities. Although this approach can possibly be explained by the fact that this was a social benefits case, it is not easy to reconcile it with the principled considerations in Perinçek, where the Court endorsed an approach of purely concrete review for most cases of the application of legislation.

Finally, the Court's approach can be confusing to the extent that it often mixes abstract and concrete elements of review in unexpected ways. For example, even in cases in which the Court usually resorts to a purely abstract review (as in cases on blanket legislation), it sometimes cannot resist inserting elements of concrete review in its reasoning. The hybrid judgments can be equally puzzling, especially for national authorities, because they do not make clear if any problems identified can be redressed on an individual level (eg by paying compensation) or if legislative amendments are needed to ensure Convention compliance in subsequent cases. ${ }^{118}$

118 The answer to this question in the cases discussed in Section 3.4 seems to be relatively straightforward: probably both. Indeed, the message conveyed by the Court in such 


\section{Conclusion - What Way Forward?}

It can be concluded from the case law analysis presented in this article that the Court's approach to the abstract or concrete review of the reasonableness of legislation is not fully consistent. Although the default and preferred position of the Court seems to be an individualised, concrete review of the circumstances of the case, there are many instances where the Court's approach is rather more abstract, or elements of abstract review are mixed into the Court's assessment of an individual decision. This situation may raise the question of whether a more principled and consistent approach would be called for and, if so, how it could be given shape.

To answer this question it is useful to recall that the choice between abstract and concrete review is closely related to the Court's double role of offering both individual and general justice or, put differently, of providing both individual redress and general interpretations that may be relevant to other cases than the one before the Court. ${ }^{119}$ Although some have argued that one role ought to be favoured over the other, it is submitted here that there is great value in combining the two roles. ${ }^{120}$ The Court's general justice role allows for a general improvement of human rights standards throughout Europe, as the Court itself has also emphasised. ${ }^{121}$ At the same time, the many violations the Court finds each year demonstrate that it continues to be important to have a system in place where individual victims can obtain redress for the harm they have suffered. Moreover, the two roles are mutually reinforcing and constantly feed into each other. Individual cases can disclose concrete indications of systemic human rights problems, or they may raise the Court's attention to a lack of clarity of the meaning of certain provisions of the Convention. The Court can help to solve such structural problems by not restricting its review to the facts of the case but (also) identifying general principles of interpretation or application of the Convention. Similarly, it can do so by reviewing legislation with an eye to identifying structural or systemic problems giving rise to an individual violation of the Convention. In turn, these general interpretations and abstract judgments can be useful in the assessment of specific cases and in offering individual redress.

If it is accepted that offering individual and general justice are therefore equally important, it is possible to arrive at some evaluative conclusions as to

hybrid judgments may seem to be that there is work to be done both on the general level (amending legislation) and on the individual level (offering just satisfaction).

119 See the introduction to the present article and see similarly, Tulkens (n 22) 35 .

120 Cf also Gerards and Glas ( $\mathrm{n} 1) 15$.

121 Djokaba Lambi Longa v the Netherlands App no 33917/12 (ECtHR, 9 October 2012), para 58. 
the approach the Court should take to the issue of abstract or concrete reasonableness review.

First, the Court's default position can be embraced, which is that it primarily should offer individual justice by arriving at a finding that is relevant to the individual case and that takes account of the particular circumstances of that case. In particular, in all cases where the Court finds that the legislative system is, overall, adequate, fair and reasonable, and a good system of legal remedies on the national level is offered, it should still look into the merits of the individual case. After all, as the Court has often remarked itself in the cases discussed in Section 3, the concrete case may disclose a situation of individual hardship or of arbitrary or disproportionate application, which can be discovered only if the concrete circumstances of the case are assessed. For that reason, in a case such as the bedroom tax case, the Court should not have stopped its reasoning after having concluded that the overall legislative system was fair and reasonable. It should have continued to examine whether, in the concrete situation of the applicants, the newly-introduced legislative system caused an undue hardship. In such cases, a two-step approach would be the best possible option to allow the Court to fulfil its double role of offering both general clarity and individual redress. The other way around, the Court's role in offering general justice - by providing general interpretative guidance and identifying structural and systemic violations - implies that it cannot always restrict itself to a purely concrete review either. Even if a case would allow for an easy solution because it discloses a clearly arbitrary decision in an individual case, the Court should keep an eye open for any more general or structural flaws in the underlying legislative system. Again, the best way to do so would be by using a two-step approach as the default option, which means that the Court, in principle, should first examine a piece of legislation or a policy measure in general terms for its compatibility with the Convention before it starts looking into the concrete consequences of its application to the case before it.

This does not mean that a two-step approach should always be applied. This can be different in those cases where the Court has already decided to adopt a purely abstract review, such as cases of direct review of legislation, or cases in which requirements of legal certainty and the rule of law, or possibly capacity considerations, justify that the Court focusses on general reasonableness only. The same holds true for cases where the finding of a violation after abstract review offers full redress in the individual case. It must be emphasised, however, that in such cases the Court should restrict itself to an abstract review and not mix in any concrete elements. Such mixed approaches cause confusion and give an unclear message to the national authorities, which does not sit easily with the Court's task of offering constitutional justice and providing clear general principles for Convention application. 
Were the Court to use the two-step approach as a default option and only rely on abstract review in cases where this is fitting, this would be neatly in line with the double role it has to play in the overall Convention system. Moreover, it could help reduce the currently existing inconsistencies in its case law and avoid confusion as to the proper object of its review. This would make it easier for parties to the Court's cases to know where to focus their arguments, and also for the Court's judges to know what factual elements to focus on. Thus, with relatively limited changes, much improvement could be achieved. 